\title{
Cultural Comparison of Leisure Concept and Behaviour among Residents of Ibadan and Benin: The Role of Culture and Leisure in Improving and Sustaining Community Cohesion, Happiness and Wellbeing
}

\author{
V. O. Ighodaro \\ Sports Complex University of Benin, University of Ibadan, Nigeria
}

Copyright $\bigcirc 2019$ by authors, all rights reserved. Authors agree that this article remains permanently open access under the terms of the Creative Commons Attribution License 4.0 International License

\begin{abstract}
The immense cultural diversity and natural beauties embedded in the communities of Oyo and Benin explains the wide array of leisure opportunities available in these regions. Culture and leisure are binomial, removing ethnic and political obstacles and facilitates dialogue among the people. Promotion of culture and leisure can serve as a tool to address and tackle unhealthy lifestyles and empowering communities, families and individuals for social development in the communities within the metropolises and across other African regions, providing the youth with better opportunities for a happier life and wellbeing. Benin City, in Edo State, South-South Nigeria and Ibadan in Oyo State, South-West Nigeria respectively, is some of the areas with diverse cultural practices. Some of these cultural practices which endured centuries of practice work for the people of these areas, as it concerns health and wellbeing through leisure activities, and affect the behaviour of the people who are the culture bearers. There is a growing recognition that there is the freedom as a people to express our cultural identity which we are and celebrate our cultural differences which further strengthens the interactions within us and with other cultures, creating opportunities for togetherness and communal living for happiness. The development of inter-cultural strategy to leisure in the above settlements and the participation in creative activities with the interpretations and expression of their arts, history, heritage and traditions can promote access to leisure, raise awareness that can bring about social change and promote leadership. Therefore, participating in cultural leisure activities can enhance community cohesion, peace and strength. The purpose of this document is to identify the existence and practice of cultural leisure activities among residents of Oyo and Benin kingdoms and create the understanding to engage more effectively and collaboratively with each other and bring creative solutions by communities, families and
\end{abstract}

individual engagement in cultural leisure activities. This study therefore investigated the activities that people in these communities do for fun during their free time, their favorite ways of spending free time and factors that shape the experience of leisure. Semi-structured interview was used as the method for data collection with fourteen respondents. Constant comparative analysis was used to analyze data comparing different categories and observing any uniformities or differences. The population consists of adults' residents in Ibadan and Benin. Purposive sampling technique was used to select the respondents for the study; a self-designed, validated and structured questionnaire for the study was used. It is recommended that: quality social interaction that encompasses the need to engage in some forms of activities for ourselves and people, the existence of supportive relationships and social cohesion should be encouraged to further create an atmosphere that is calm and void of quagmire.

Keywords Culture, Leisure, Cohesion, Peace, Happiness and Wellbeing

\section{Introduction}

Participation in cultural leisure activities can enhance community cohesion and strength and are seen as a valuable forum for social examination and debate, a means of fostering the creativity, innovation, and dialogue necessary for economic and social development, many cultural leisure activities bring health benefits by providing relaxation. Cultural and artistic activities, and other active activities during cultural leisure can have a positive impact on individual's happiness, this approach has the advantage of being able to consider all these activities at the same 
time, accounting for the impact of each of these activities on individual happiness levels. Cultural participation, which is related to an individual's wellbeing, is seen as a symbol of self-presentation and helps define socioeconomic status. In addition to maintaining group boundaries and social inequalities, cultural preferences also define individual identities. Leisure activities define the aspirations of different reference groups and are in the end, positional goods, (Lamont and Molnar, 2001).

The concept of culture and leisure allows us to acknowledge some inherent aspects of human nature, such as our need for identity, our creativity, history, attunement to aesthetic meaning, spirituality and our propensity for play and enjoyment. Given the wide variety of factors these concepts cover, one measure of progress might focus on our freedom to express our cultural identity, which we are and to celebrate our cultural differences. Another might measure our ability and willingness to interact with other cultures, or to participate in the arts, sports and recreational activities, Indeed, the myriad of activities and opportunities within leisure and culture we can pursue and enjoy today will contribute to our overall quality of life and wellbeing (Australian Bureau of Statistics, 2004). According to (UNESCO, 2009), Culture is the set of distinctive spiritual, material, intellectual and emotional features of a society or a social group that encompasses not only art and literature, but lifestyles, ways of living together, value systems, traditions, and beliefs.

Nigeria is one of the largest countries in Africa with a multi-ethnic society, with diverse cultures of peculiar nature and diverse practices. Nigeria is made up of people from different ethnic groups and cultural practices with the dominant groups being Hausa, Yoruba and Igbo. It has more than 250 ethnic groups with different cultural practices, Oyo and Benin Kingdoms are twin kingdoms located within an entity called Nigeria possessing ties of cultural homogeneity; a high degree of loyalty and adherence to certain basic institutions such as family patterns, religion, and language; distinctive folkways and mores; customs of dress, art, and ornamentation; moral codes and value systems; patterns of recreation; some sort of object to which the group manifests allegiance, such as a monarch, a religion, a language, or a territory; a consciousness of kind, a we feeling; common descent (perhaps racial), real or imagined; and a political unit (Lucas 2003, Sowunmi, 2004; and Ojua 2012).

Oyo and Benin are two distinct areas with diverse cultural practices. Some of these cultural practices which have endured centuries of practice work for the people of these areas, with regards to health and fitness through leisure activities and affects the behaviour of the people who are the culture bearers. Also, some of these cultural and traditional practices however have stood the test of time and have positive values. It has been established that people in the current parts of Nigeria known as Oyo and Benin were at a time in history, shared some common origin, there have fortunately survived from these ancient kingdoms some remarkable and very beautiful bronzes and terra cottas, some of which rank among the masterpieces of world sculpture, records had it that the Yoruba version of the myth of origin tells that Oduduwa was an Eastern prince driven out of his kingdom. After long wanderings he conquered the local inhabitants of Ife where he settled Kunle, (2004).

He had seven children who were the ancestors of the Oba of Edo and the six crowned rulers of Yoruba land, namely the Olowu of Owu, the Onisabe of Sabe, the Olupopo of Popo, the Orangun of Ila, the Alaketu of Ketu, and the Alafin of Oyo. In this story the non-Yoruba kingdom of Edo is included in the very beginning of Yoruba land, and both Edo and Yoruba traditions agree on the circumstances. History has it also that the rise of Benin and Oyo coincided with the decline of Ife 'as an effective political empire, though it has retained its primacy as a religious metropolis to the present.' None ever disputed the fact that Oranmiyan the last born of Oduduwa also ruled the Benin Kingdom. Oranmiyan - the famous and an unequaled Yoruba prince and warrior was the only Yoruba royal enigma to have ruled over Benin Kingdom, founded and became the very first Alaafin of Oyo and later came back to become the Ooni of Ife! He, it was who restructured Benin Kingdom, married in Benin, had two sons and one of the two sons later became Oba of Benin monarch.

It is on record that Ogiso troubled dynasty was discarded and subsequent kings in Benin became known and addressed as "Oba" till date, based on the order established in Benin Kingdom by Oranmiyan. Even up to 1939, Yoruba language was the official palace language in Benin. No wonder then that many Benin families bear Yoruba names! And what about designs of the Benin palace after the renowned and historical Oduduwa palace in Ile-Ife, and why did Benin allow the last child of Oduduwa to be made a king over them or his descendants, if there was no blue blood connection? Oba of Benin gave a detailed account of fact of history that is very difficult to dispute Kunle, (2004). The twin kingdoms of Oyo and Benin remained two of the most powerful kingdoms on the west coast of Africa up until the establishment of the British Protectorate at the end of the nineteenth century and shared so many things in common in names and culture, which must be the reason why it is very difficult to dispute the version of Omonoba-UkuAkpolokpolo; Oba Erediawa of Benin kingdom and Ooni of Ife in a separate forum. Both versions of history from Oba of Benin and Ooni agreed that Oramiyan the last son of Oduduwa returned to Ife from Benin after he installed his son, Eweka the first as Oba of Benin, Sowunmi (2004).

It is essential to have an idea about cultural practices of some communities because, the practices a community adopts, fulfill certain purposes in the culture bearers (Idehen, 2007). The cultural behaviour of the people affects 
all aspect of life including social relationships and contribution to social functioning and development. All people, no matter the race, have their beliefs and leisure practices. Each society and community has its peculiar way of doing things and these practices go a long way in influencing the people's perceptions, attitudes, and behaviour (WHO, 2007). Leisure behaviour is defined as the actual participation in structured and unstructured activities which is perceived by participants as a leisure activity. Culture refers to the way of life of the individual members or groups within a society, how they dress, their religious ceremonies and leisure pursuits (Oni, 2005). Adedimeji (2006) declares that "to be removing from one's culture is to be deprived of one's identity. To lose one's identity is to be tossed in the wind fluttering along like a leaf separated from its tree. Anyone that loses his cultural or linguistic legacy is bound to expire. On the other hand, leisure is those activities undertaken by a person for enjoyment, recuperation, or relaxation and includes hobbies, recreation and cultural and artistic pursuits. Leisure time gives people an opportunity to recover from pressures of work and other commitments, to bond with family and community members, to pursue their interests and to reflect on their life direction and meaning

This study therefore looked at the existence and understanding of the concept of leisure among residents of Oyo and Benin, Nigeria with specific emphasis on age, gender, and marital status; also to identify forces that shape the experiences of leisure and leisure behaviour among the people of Oyo and Benin respectively. Each culture should be given the opportunity to express how they define and understand the very concept of leisure, furthermore, the majority of the existing research on the topic has explored the understanding of leisure among immigrants or minority groups within western society, while the understanding of the concept of leisure might be different among these groups of people living in their home community. Such issues might be of particular importance when one considers cultural richness and diversity of Oyo and Benin communities in Nigeria. Not only would we benefit in comparing the phenomenon of leisure inside two distinct cultures, but we can also determine the transformation in the understanding and the practice of leisure between Oyo and Benin residents as they settle in either community in Nigeria. The cultural richness of Africans opened a wide avenue for recreation after the day's works. Recreations as well as physical exercises like dance, acrobatic and gymnastic displays, masquerade dance and cultural festivals are often done for enjoyment and refreshment. Thus, through playing games, sports and traditional religious festivals, the African child develops physical, emotional, aesthetic and social assets, which will serve him in good stead when he grows up; but there is less leisure now than in the middle Ages, when one third of the year consisted of festivals and holidays (Priestly, 2005).

In Nigeria, there were lots of other avenues for releasing tension in this area, these includes traditional festivals, moonlight stories, meetings at the village square, hunting, dancing, wrestling, fishing, swimming and playing various types of games during their leisure to become well adjusted, full of fun and happiness (Ipinmoroti, 2004). The fast growing amount of leisure time in Nigeria also underscores the need for recreational pursuit. Critcher, Bramham and Tomlinson (2001) argued that the result of increased leisure that is not properly utilized can manifest in various societal problems ranging from idleness, violence, alcoholism, drug abuse and other related vices. Meanwhile, judicious utilization of leisure hours provides an opportunity for everyone in the society to satisfy his/her basic human needs for self-expression, physical, emotional, mental and social, (Odumuh, 2004).

An international expression of the importance of leisure can further be found in the "Declaration of human right" of the United Nations (United Nations, 1998; UN-enable, 2006). It recognizes the right of everyman to rest, to leisure, to freely participation in cultural life of his community and also emphasizes the importance of ensuring that even children have the full opportunity for play and recreation which will fully promote the development of his personality. The benefits of active involvement in leisure have attracted individuals, groups and governments to it. Even world organization such as World Leisure Organization, World Tourism Organization, World Travel Tourism Organization, International Council for physical, Health Education, Recreation and Dance, United Nations Education and Scientific Commission etc., are actively involved in propagating leisure programmes around the world because of its tremendous contributions to individual happiness and community development.

\section{Statement of the Problem}

It has been observed that the cultural practices that the people of these kingdoms once endeared and adored, which also have affected the lives of the people positively with regards to community cohesion, strength and peaceful co-existence, is now given less attention with gross negligence due to modern leisure, therefore the cultural leisure practices with its numerous social benefits which includes: enhanced good neighbourliness, reduction of social isolation and community involvement; social mobility and pride in community; environmental awareness; enhanced world view as a benefit to community; cultural awareness, cultural identity; cultural acceptance of others and the promotion of oneness through interactions have been polluted at the exchange of modern leisure and there is less leisure now than in the middle Ages, when one third of the year consisted of festivals and holidays. The instrumentality of modernization has corrupted and affected tremendously the in-depth participation in cultural leisure activities among the people.

The cultural practices adopted by the people of these 
kingdoms in the past have a lot to do with creativity, identification, History, spirituality and cultural aesthetics. It is therefore essential to revamp and restore these practices through the instrumentality of traditional institutions by educating the people of these domains, enlightening them on the roles cultural leisure can play in their lives, both at home and in the Diasporas. Perceptions concerning the extent to which the people in the twin kingdoms use and value their free time should further be strengthened and examined more closely as a potential source for leisure participation.

Through immersion in and observations of the people's culture as well as questioning of members of that culture, one can map an unknown element inside a culture. That is, the people of that cultural background should be given the opportunity to establish the parameters and essence of the element in question, hence the need for this study.

\section{Purpose and Objectives of the Study}

The goal of the research is to investigate the concept of leisure and its participation among Ibadan and Benin indigenes and to assist the people to understand and engage more effectively and collaboratively with each other and bring creative solutions by communities, families and individual engagement in cultural leisure activities. In particular, the objectives of the study are:

1. To identify the existence and the understanding of the concept of leisure among residents of Ibadan and Benin City.

2. To identify the similarities and differences in leisure activities among Oyo and Benin residents.

3. To identify how leisure is categorized among Ibadan and Benin City residence.

4. To identify the constraints to participation in leisure activities.

5. To establish the leisure behaviour of the people of these metropolises

6. To identify changes leisure participation had on the behaviour of the residence of these metropolises

7. To establish the benefits of participating in leisure activities among residents of Benin and Ibadan as it affects their wellbeing.

\section{Operational Definitions of Terms}

Concept: Conceived ideas of leisure understanding by Ibadan and Benin communities and the proposal with a particular emphasis on the benefits accruable from the idea of leisure participation

Culture: Culture is the set of distinctive spiritual, material, intellectual and emotional features of a society or a social group that encompasses not only art and literature, but lifestyles, ways of living together, value systems, traditions, and beliefs.

Wellbeing: Experience of a state of successful, satisfying and productive engagement with one's life.
Happiness: A pleasurable and satisfying experience which comes through participation in cultural leisure activities.

Metropolis: Conurbation City of Ibadan and Benin with significant economic, political and cultural regions chosen as an important hub with international commerce and communication connections for cross-cultural studies in leisure behaviour.

Cross-cultural research: Distinct Comparison and contrasting of Ibadan and Benin leisure cultures with the intention to finding out their similarities and differences in the understanding and meaning of leisure concepts.

Leisure: Purposeful and intentional use of free time to engage in self-selected activities that are meaningful and intrinsically motivating to the individual in that they are enjoyable, fun, refreshing and pleasurable.

Leisure Activities: Legally and acceptable type of activities that is done during ones discretionary times

Leisure Behaviour: Actual participation in structured and unstructured leisure activities.

Cultural Leisure: cultural experiences through activities: by live attendance, by home consumption, and by community practice.

\section{Significance of the Study}

- The study is expected to state the important role leisure can play in the lives of the people.

- A cross-cultural study of leisure concept of this nature can test new grounds in examining the understanding of the concept and meaning of leisure among non-western populations like Ibadan and Benin City.

- The study may encourage the people to create more opportunities for leisure participation because of the immense benefits (intrinsic and extrinsic) rewards derivable from participation.

- The study may help leisure practitioners in designing recreation programmes for the population that will consider the demands of family recreation amidst the complex traditions and norms that are still practiced by members of these groups. This of course may restore unity, and peaceful co-existence which have been caused by family dysfunction.

\section{The Participants}

The interviewees in Ibadan metropolis will include five males and two females primarily of working class status who will represent a variety of occupations. A similar conduct will be carried out in Benin metropolis with six males and one female.

\section{Findings of the Interview}

\section{The Participants}

The interviewees in Ibadan included five males and two females primarily of working class status who represented a variety of occupations. 
Table 1. Participants in Ibadan

\begin{tabular}{|c|c|c|c|}
\hline Name & Adedoye Rasheed & Chief Igbayiloye olanwuni & Motunrayo Adijat \\
\hline Gender & Male & Male & Female \\
\hline Age & 35 & 60 & Ibadan North-East \\
\hline Local Govt & Ibadan NW & Ibadan N & Mapo Hall \\
\hline Community & Ijokodo & Agbowo & Hair Stylist \\
\hline Number of yrs in Ibadan & 18 & Teacher & Single \\
\hline Occupation & Pool Vendor & Married & 0 \\
\hline Marital status & Married & 7 & \\
\hline Number of Children & 6 & & \\
\hline
\end{tabular}

Table 2. Participants in Ibadan

\begin{tabular}{|c|c|c|c|c|}
\hline Name & Abike Olusola & Michael Gbadebo & Olalekan alao & Jubril Jolayemi \\
\hline Gender & Female & Male & Male & Male \\
\hline Age & 40 & 46 & 38 & Ibadan N \\
\hline Local Govt & Ibadan S.E & Ibadan S.W & Ibadan N.W & Bodija \\
\hline Community & Challenge & High court & Beere & 16 \\
\hline Number of yrs in Ibadan & 25 & 35 & 20 & Construction Worker \\
\hline Occupation & Unemployed & Trader & Musician & Single \\
\hline Marital status & Married & Married & Married & 0 \\
\hline Number of Children & 3 & 5 & 1 & \\
\hline
\end{tabular}

The interviewees in Benin included six males and one female primarily of working class status who represented a variety of occupations.

Table 3. Participants in Benin

\begin{tabular}{|c|c|c|c|c|}
\hline Name & Richard Idahosa & West Salami & Philip Ewanbor & Oni Imuentiyan \\
\hline Gender & Male & Male & Male & Male \\
\hline Age & 63 & 54 & 47 & Oredo \\
\hline Local Govt & Ikpoba Okha & Egor & Oredo & Agbonmoba \\
\hline Community & Aduwawa & Uselu & 40 & 53 \\
\hline Number of yrs in Benin & 40 & 30 & Insurance Broker & Pastor \\
\hline Occupation & Coach & Coach & Married & Married \\
\hline Marital status & Married & Single & 0 & 3 \\
\hline Number of Children & 3 & 0 & & \\
\hline
\end{tabular}

Table 4. Participants in Benin

\begin{tabular}{|c|c|c|c|}
\hline Name & Vivian Ighodaro & Honourable Mike Aholor & Julius Ibuedefe Obadigie \\
\hline Gender & Female & Male & Male \\
\hline Age & 42 & 60 & Oredo \\
\hline Local Govt & Ikpoba Okha & Oredo & Ekewan \\
\hline Community & Eyaen & 60 & Technical Coach \\
\hline Number of yrs in Benin & 40 & Bronze Caster & Married \\
\hline Occupation & Teacher & Married & 3 \\
\hline Marital status & Married & 6 & \\
\hline
\end{tabular}


Findings of the Interview (Qualitative)

\section{Benin}

The findings presented in this section are based on interviews with Benin indigenes from Edo State and are divided into themes. Favorite ways of spending free time among the local population, understanding of the concept of leisure for members of the community, how the concept of leisure is categorized and forces that shape the experience of leisure among the people

\section{Richard Idahosa 63, Male, Coach, from Aduwawa in ( Ikpoba Okha L.G.A)}

What are the activities that people in this community do for fun during their free time Like in my area, precisely, we play draft but are not always common like I told you, people you have this same like mind with, people who are of the same age group, and that are of the same level of education. Others spent their free time on watching $T V$ (Sports), listening to radio, children play ball on the streets with their pairs without supervision, while the women are fond of gisting because most of them have their businesses in their compounds, sell and plait hair and the likes. Some of the men go to bear parlors to drink, watch premier league matches, and discuss it on Saturdays. This is where they have their fun, sit down together, discuss and chat together, and subsequently share ideas.

The only free time I have is when I close from work, watch television, and then sleep off. I also listen to sweet gospel music, do some clean up within my compound, watch my car, and do some cycling and other general exercises to keep me going. I also enjoy religious ceremonies and I partake in them. This also makes me happy with the fun in it.

\section{What is so special about the activities that you like to do for fun?}

The fun I like participating in when I'm free is cycling and playing chess with my children. This is very unique and it very intelligent a game, it discovers abilities, and skills that an individual possesses. It will eventually make them have the right attitude that could assist them to perform well when they are matured. I feel happy; and homely when I participate in them and with them.

\section{What does leisure activities means to you?}

Eghe-miobo i.e. (free time) It is my free time to do those things that $i$ do that gives me fun and not stress, that makes me happy, makes one to leave tension and forget about other pressing issues that may border my mind. Free time does not come so easily, they come when I am less busy. When I am busy, other things can take my time, maybe those things that are piling up as a result of work schedule, and if $i$ am able to clear them, and I have free time, I use it for myself. Well as a coach, we have time for everything, the time will take out for coaching children, passing instructions, they are part of the leisure and part of our job we do on daily bases, but it also depends on when the students have time because their time table sometimes is jam-packed and may not be readily available.

\section{What do you call the activities you do for fun?}

The language I have for it precisely is fun-full and stress-less activities, those things that $i$ do that gives me fun and not stress, that makes me happy, makes one to leave tension and forget about other pressing issues that may border my mind.

\section{Are there any fun activities you like to participate in but are not able because of lack of money?}

Yes, not necessarily lack of money but lack of space and people around. We don't have space, open space where you can play with your kids and have fun with them in the neighborhood, probably a big space which is available for everybody to play. It might not really require resources but it requires the people who are within the neighborhood who comes around to make use of that space, like I do com to sports complex to jog with people around and chat with them. That gives me a lot of fun but if I don't leave my house, I will not enjoy the fun because what I don't see about myself, others will see it from their own angle. We recreate together, we chat and try to put ourselves in order; that's just the essence of it all. Some times; we don't have people of like mind who are of the same category, who share the same ideas with you, participate in same activities.

\section{Salami West 54, Male, Coach, from Uselu in ( Egor L.G.A)}

What are the activities that people in this community do for fun during their free time and your favorite ways of spending free time?

Benin people mostly engage in pepper soup joints, restaurants after daily routine and schedule. I see it as a form of succor to depression, a kind of relief from stress they are all involved: family stress, emotional stress, financial stress and most of the people who patronize these joints are sponsored by their friends who come from far and near with the cash in their pockets.

The economic hardship and other distractions have really impeded leisure as a part of life. Leisure is activities you undertake after your daily routine and your rest period. Those days we go to Ogba Zoo, Ring-road Park, Airport as part of leisure during public holidays (Christmas, Easter, Independent day celebrations etc, but these days, the lack of social facilities such as basketball court, swings, trampolines etc. have all disappeared from our schools, both primary, and post-primary schools and other public centers. Here in University of Benin, there is only one form of recreation facility which is the swimming pool.

I try to create much time in my daily life; I see it as a 
necessity /part of life after daily routine as a coach, I go to relax in my house watching a lot of enlightening programmes like documentaries about history, issues on natural disasters like earthquakes, terrorist attacks all over the world. I also engage in fitness exercise as a form of relaxation.

\section{What is so special about the activities that you like to do for fun?}

The specialty is that it helps me to build my mind, enhancing the appeal of the entire body structure physiologically, creating eminent personality. I see my leisure as very significant after my spiritual life and wellbeing. I enjoy myself more when into my fitness programme.

\section{What does leisure means to you?}

Happy activity, progressive activity that is spiritually inclined. The essence is to receive basic satisfaction for our community and environment and to assist the country as a whole. I see leisure as a succor to life, as a fixed spiritual injunction to life. Jesus Christ engaged in leisure, went to marriages to perform miracles. His earthly father was a carpenter, he must have had a vocational education from his father, and therefore, leisure is significant and of a great necessity to every living specie created by God.

\section{What do you call the activities you do for fun?}

I call it my very important period and solution time because I assist to build souls, save souls. I create leisure in my work place helping people to reduce blood pressure, interacting with people and solving problems, proffering solution to stress. We also teach the sick even in the hospitals on how to raise the pillow up and down to help their cardiovascular endurance and the person put a smile on the face.

\section{Are there any fun activities you like to participate in but are not able because of lack of money?}

Yes, there are lots of activities I would have loved to do like build an indoor sports hall and put in all social facilities. That is my plan but is capital intensive but if I have more resources at my disposal, I would relocate and build branches inter-state within Federal Republic of Nigeria such as Lagos, Abuja, and Port-Harcourt with social facilities.

Philip Ewanbormale,47, Insurance Broker, from Agbonmoba in (Oredo L.G.A)

What are the activities that people in this community do for fun during their free time?

If I might take it from what I have seen, people move early in the morning around 7: 30am to their places of work and close at 4pm and back to church and from church to their respective homes. Those not involved in government services, do their personal businesses, go to market for shopping at their free time while others go to beer parlours where they drink beer or minerals to refresh themselves and some goes to bookers, eat and relax, only younger people that move down to the primary school to play ball. Others participate in meetings, associations, solidarity groups, especially Sundays Saturdays and Sundays at weekends, you see them together, and they discuss, sings, clap and dance, then eat together, share problems together. It gives them joy and anyone that is not around, is checked on, that's majorly what the men and women do.

\section{Your favorite ways of spending free time?}

For me, I hardly have free time, except I make out time for myself to just relax and that is because from my place of work. I come down to the church in case of counseling to be done. When I am feeling headache, stressed up or tensed up, I take a nap or move down to the keyboard and play piano to refresh myself. I also sing and play drums at times and whenever I do these things, I forget the tension, relieved and feel relaxed/refreshed to continue for the day.

\section{What is so special about the activities that you like to do} for fun?

Fun in the matter is what makes me happy and gives me joy, what relaxes me and refresh me, to be pleasurable toward evening time. I always refer to the keyboard and by the time I play, the sound, music coming out arranges me, put me in in the right perspective, in the right frame of mind. For visiting my father, there is something re-uniting and igniting. He tells stories about the family and things in the past.

\section{What does leisure means to you?}

Is the time I create for myself to have relaxation.

What do you call the activities you do for fun?

I call them recreational activities, reviving and refreshing activities

Are there any fun activities you like to participate in but are not able because of lack of money?

I think another recreation activities I would love to do is going for gardening, planting and taking care of plants and also going to sports complex, any organized place where maybe I can watch football, tennis to diversify, instead of keyboard alone. To do all of these, need financial involvement.

\section{Oni Imuentiyan male, 53 Pastorfrom Esigie in (Oredo} L.G.A)

What are the activities that people in this community do for fun during their free time?

It depends on what we call free time like late in the 
evenings; they go to where they will relax themselves. Some go to bear parlour, those who are Christians normally goes to church while those who especially close early in their places of work goes for recreation, either playing football or watching football, depending on the work one is doing what is given you pleasure when doing it. Children go to school during school hour but plays football late in the evening, watch television. Generally, there is no time for everybody to do the same thing at the same time.

\section{Your favorite ways of spending free time?}

Basically, the truth is that if not you mentioning it now, I don't think I actually structured time for leisure time activities because as a pastor, somebody can call you at any time except you deliberately off your phone and you want to rest or perhaps, may be attending to family matters, relations and extended families.

\section{What is so special about the activities that you like to do for fun?}

The activities I found myself doing most of the time are counseling people both inside the church and outside the church. The truth is that, counseling people gives me joy and then when I see people happy after counseling, I get joy from it and more especially, seeing people doing what we expect from them to do. And visiting my aged mother on Sunday after church, relaxing and talking to her, with my children, which they love.

\section{What does leisure means to you?}

Leisure means period you are free from work. The work here is actually in the ministration, therefore if also mean talking to people, otherwise called "counseling". Time you are resting although I don't plan it but as it comes, I try to use it to have rest.

\section{What do you call the activities you do for fun?}

I may call it a hobby-fun because most of the things we do comes voluntarily. Most times, is not pre-meditated and we see the inspiration coming, it gives me joy to do more, it is my vision anyway.

Are there any fun activities you like to participate in but are not able because of lack of money?

So many, I would love to take my family out for shopping abroad maybe rest for a while or visiting friends not in this country. Even they have invited me but I have not been able to go to those places. I would have actually love to find out the way they do their leisure there abroad.

\section{Vivian Ighodaro female, 42, Teacher from Eyaen in (Ikpoba Okha LGA)}

What are the activities that people in this community do for fun during their free time?

Well, in this community, the time is spent hanging out with friends, drink in restaurant and eating meat as well. The women go to work and market to sell; they don't really have time for leisure because of household chores and going to church. While some others go to town meetings clubs, birth day ceremonies etc. The children play football; girls watch movies, youth putting wood together to play table tennis and snooker.

\section{Your favorite ways of spending free time?}

I don't really have so much free time, I go to work in the morning by 6:45am to return by 5pm, the only time I am free is Bible study when I sit down and listen to messages and it is not prompted by any because as a family, we believe in Christ and we go to church together and pray. The one I practice now is watching films when my husband and children are watching films, they call me, involve me in it, and I have fun.

What is so special about the activities that you like to do for fun?

Well, nothing really special but you need to sit down and see yourself asking questions and interacting with the children and you find out that your nerves are relaxed

\section{What does leisure means to you?}

Well, it means a form of recreating, relaxing, having time to relax. I feel very happy and relieved from stress.

\section{What do you call the activities you do for fun?}

They are called recreational or free time activities; it can be called, time to relax, free time, fun time or happy time.

Are there any fun activities you like to participate in but are not able because of lack of money?

Yes, there are some, maybe in cinemas or sport centers that is if there is money. I would have loved to register in sport centers, take the children out to have fun in zoo and so on.

\section{Honourable Mike Aholor male, 60 Bronze Caster and a Politician from Igun (Oredo L.G.A).}

What are the activities that people in this community do for fun during their free time?

Benin is an ancient place; we have so many different type of work that occupies us. Among the things done here is bronze casting job in the street, some carving, those that reside at Egbesamwan is the original home of carving just as Igun is the original home of bronze casting in Benin. We have leather makers: "Isekpuku", they reside in a place around forestry. All these are so many deeds of workers exclusively for the Monarch himself, in the past, we work for the Oba but today, it has gone commercialized, everybody now sell to people in the world as perhaps, maybe the patronage of the palace alone cannot fend for every person now. The Monarch is still in charge and owns 
our job. If he request for it, you have no option than to honour the Oba.

Yes there are so many games that occupied the Benin people such as: a game called Ogirise played in the night, not mainly in the night, Ayo games called Osewe strictly for the young people then and the elders involves in Akhuwe and Edoh, the English people call it riddles and jokes, they are so many.

\section{Your favorite ways of spending free time?}

You are seeing me just sitting, maybe for now I am not working, I must have worked in the morning time today but this time around, I am not stressed and I do have time for my wife. Like you can see on this table, someone just left, we were playing ludo game, here we relax and play the Ayo game called "Ogirise" at my free time. This business of bronze casting is a part of me, an innate thing.For me, it is business and in another way it is fun. I also spend my free time in playing politics and attend festivities such as "Igue" festival, a festival that is attended people all over Nigeria and in the Diaspora and "Ebe-Ewere" at the end of the year is another fun time celebration and fun for us to usher into another new year. It is really fun be a part of this. I just resigned my chairmanship position for another thing, I served in advisory capacity to the government. I was a one-time councilor, organizing secretary of the party and other many positions. In addition to this, I am in company of my wife and children, after work, stayed together, crack jokes and discuss the day's business and checking the children books. These are all what I enjoy most during my free time. In addition, major public holidays are very important to me and my family for recreation and relaxation time.

\section{What is so special about the activities that you like to do for fun?}

It is so special because I don't see my children as just children, I see them as my close friends, even my wife, she my friend. You could see us cracking jokes, when you see us, you may marvel like as you will be surprise. It is special to me because they are close to me, that is why I cannot go out and spend a week or more somewhere else because they will be missing me and I will be missing them as well.

\section{What does leisure means to you?}

It means feelings in the blood line, you might not understand but I have time to study them. And I feel overwhelmed and happy when I am with them.

\section{What do you call the activities you do for fun?}

I tagged it friends activities, fun time activities, and it is not wrong if is also called free time,

Are there any fun activities you like to participate in but are not able because of lack of money?

Of course yes, I am not too rich but I think I'm comfortable with the little I have. But there are things actually I ought to have, you know there is nothing wrong if my children attend very good schools and if I have enough money, I can buy them good cars and allow them to live well, take them out to other places like Dubai and other countries around the world for recreational activities and to spend our leisure time together.

\section{Julius Ibuedefe Obadigie male, 57 Technical Coach, from Ekewan in ( Oredo L.G.A)}

\section{What are the activities that people in this community} do for fun during their free time?

In my community, some play Ayo game called (Oguruse), some plays draft because there are no historical centers for volleyball and the rest so most of them look for the nearest small open space for football. Children engage In football, while the adults involves in putting one leg in the floor and use the second leg to wrap the next one, they do it while moving round and whoever lands on his two legs is out of the game until they have the final winner and some of them do it in the neigbourhood.

\section{Your favorite ways of spending free time?}

I have less free time but at weekends (Saturdays and Sundays) is my free time to do my fun activities; I am restricted to participate in some because of finance because I like travelling a lot. I travel to historical sites. but however also, with this new methods of downloading films from the internet, since I come home from work late, before I get home, my wife download films of which after resting, a little while, I go close to the computer to watch the films. Somehow it has been a form of relaxation for me. And also when I am with my family (wife and children) and friends at the institute of Benin Studies, as alumni, we all meet at Ogba Zoo at Airport road.

What is so special about the activities that you like to do for fun?

Yes travelling to historical sites in places like the old Oyo Empire, Benin Empire, mountains, historical sites at Obudu Cattle Ranch, Olumo rock, Sherri Hills in Jos etc. These places I would love to go back there and ask more questions. I try to recall what I have read about it and seeing it practically gives me a lot of fun and knowledge that I would like to ask if there is any orator that takes care of those historical sites and know more about it and whenever I am at these sites, it is the peak of my fun.

\section{What does leisure means to you?}

First, relaxation and acquisition of knowledge which of course I will pass on to my children and younger ones. And Ifeel so great when I participate in them, I feel on top of the world

\section{What do you call the activities you do for fun?}

I call them free-for-fun activities where I have the 
revitalization of my system and thinking faculty restored and which later serves as a source of energy to be more productive in the subsequent days ahead.

Are there any fun activities you like to participate in but are not able because of lack of money?

Yes like I said, my area of interest really is historical sites and I would have loved to be in so many of these sites to see the handiwork of God outside the shores of Nigeria: Europe, America, Asia and some other continents of the world and ask more questions but the predicament is the financial implications because it is capital intensive1.

\section{Findings}

\section{Ibadan}

The findings of this part of the study are based on interviews with Yoruba indigenes residing in Ibadan, Oyo state and are also divided into sections and themes. Majority of the participants revolved around their friends. This had a direct effect on their leisure patterns. For instance, it was a way of life among the interviewees to spend most of their leisure time with their friends and, for many of them; hanging out and with friends was the most enjoyable part of leisure called 'Faaji'“Jaye ori", "Shaye". Some interviewees commented that they would sacrifice other ways of spending free time just to be with their friends.

\section{Adedoye Rashee (35, Pool Vendor) from Ibadan NW (Ijokodo)}

What are the activities that people in this community do for fun during their free time and your favorite ways of spending free time?

Remarked, "That the community members at Ijokodo hang out with one another, after work we engage in 'Faaji' leisure, at deep blue at club houses.

\section{Your favorite ways of spending free time?}

I go to smoke "regular" and have really nice time. "We just use this to rest at evening-night and also when I am making love with my woman is also my leisure, I feel happy, we feel good while participating in these activities we call "Faaji", "Jaye ori", "Shaye" etc in Yoruba language. Sometimes money becomes a limiting factor for checking friends at the other side of town" the nature of my work does not affects my 'Faaji time" there is time for everything".

Chief Igbayiloye olanwuni (60, Teacher, From Agbowo in Ibadan North)
Similar to the majority of the participants, Chief Igbayiloye claimed when there is time, for leisure $i$ drink two or three bottles, with friends and discuss, and watch football at the weekends at football viewing Centre. Leisure means a lot to me because I feel relaxed, and I know that the leisure activities I do are good for my health. Annually, $i$ do participate in "Egungun and Oke-badans festivals" and during this time, I feel tied to my culture and tradition which gives me a feeling of belongingness. He did not hide the fact that he really focuses on the particular leisure activity he is participating in per time. He feels okay and relaxes his body during his "Igbadun" i.e (enjoyment). Most of the time, I am also sticked to my radio listening to Yoruba programmes, this remind me constantly of where I come from and where I belong. This also makes me very happy and homely.

The constraint of money currently affected my desire for shopping with my family on weekends so i settles for watching premiership football matches. For instance he stated that the previous day he just ordered for 'Agbara' an alcoholic herbal drink and he went to sleep thereafter. Religion does not affect leisure, they are two different things. He however emphasized that he takes drinks as a matter of habit, and for relaxation to enjoy and live a long life.

\section{Motunrayo Adijat (33, Female Hair stylist in Mapo Hall, Ibadan N.E)}

She commented that people of her community after work sleep, young guys watch football and sum sleep in night club, but personally I go for movies, music in a quiet place. Leisure timelfree time means a free time when i can cool off and is relative, but she emphasized her pleasure in movies and music.

The special thing about my leisure is that my brain relaxes and things flow in a good way for me and music is a must for me to be able to say I had leisure for real, " i feel okay and good because apart from the fun of it many things can be learnt from music and some movies." $i$ call this kind of time "relaxation time and private time". According to this respondent, her work does not interfere with her leisure time which is the same response for all the interviewed respondents. "I go to religious gatherings and activities but not a regular or a must attendee, it's as time permits". And most of the time, I always look out for major holidays like Easter holidays, Christmas, and New year Eve etc to enjoy my free time. During this time, it is usually pump and pageantry.

\section{Abike Olusola (40, female trader in Challenge, Ibadan S.E)}

Another respondent whose opinion was sampled said resting, house chores are the leisure activities she does as well as religious programmes and some people go to check 
their friends. My favorite of all these are resting, praying, house chores and sleep. I play ludo while the others play draft. Leisure means nothing special to her because usually according to her she said female do not usually have free time per se, they just squeeze leisure time around 3-4 pm because after that the family preparations for dinner begins. I would have loved to go to shop for my kids and enjoy movies at the cinema but financial constraints affect this desire and my business does not interfere with my leisure neither do Islamic religious activities. Although, I constantly look forward to" Eid-el-Fitri, Eid-el- Maolud and Eid-el-Kabir" celebrations for fun and enjoyment as part of leisure activities.

\section{Michael Gbadebo 46, male, musician in (High Court, S.W,L.G.A)}

I get involve in leisure to avoid boredom and as an escape from the hardship of the country. We drink and some sings. If there is an artist around, he engages in them towards evening period after his work. Although leisure is not too special but I feels very happy, and enjoys myself. The leisure activities are very helpful to the extent that some of them would have died if not for "Shayosiology". We call it "Shayo"or "be happy" or "Shayosiology". My work does not in any way interfere with my leisure time. He said he does not do any festival or occasion because of the fear of been killed I do not participate festivals because of the fetish involvement and so I am afraid to die. This deprives me from going close. The leisure activity I would have also love to engage in is to go after women but $i$ do not have the money it takes to do that aside from the fact, there could be sexually transmitted diseases from such exercise.

\section{Olalekan alao 38, male, Construction worker from Beere Ibadan N-W}

In his response said "free time for me is when i relax, when $i$ am done with the daily work at around six pm till seven thirty pm (6:30-730am). The special thing about this leisure is that it saves one from down-time, boring and lonely-time. Local palm wine will be ordered for, and friends will join and add to it and so on, "Asun" (roasted/smoked goat meat) may be added to it and the fun goes on. Whenever there is money available at weekends, I go to the swimming pool to swims, in the process, interact with old friends and make new ones. Seasonal holidays such as, Independence Day, Christmas, New Year, Easter, and local ethnic celebrations are part of the time spent for leisure. "My parents have always been Christians, my mother very much so, however, she understood the satisfaction that everyone derives from the excitement leading up to Egungun festival, because of this my siblings and I are super obedient around the festival time so were many children in my neighborhood", we always look forward for it because of the excitements and fun. However, I am seriously constrained with money and this deters other better opportunities to participate in the leisure of my choice.

Jubril Jolayemi 27, male, Unemployed, (Bodija, Ibadan N)

This respondent reported a very similar view with the first male respondent from.....but he added that when the hanging out begins there is opportunity to learn a lot from other people, ideas can be caught, learnt and burdens can be dissolved from worried hearts, at times play chess and Ayo game which help me relax mentally. I am a Christian and $i$ have the schedule of my church for a day and the time to go for religious activities is separate and well defined, During other times of my leisure hours "ponmo" i.e. dried and roasted animal skin is usually added to the palm wine to enjoy with and this may not be every day. The name the community usually calls their leisure time is "Faaji", if i had more money, I would organize more leisure activities and travel with relatives, or buy car to take me to my choice destination.

\section{Discussion}

The findings of this part of the study are based on interviews with the indigenes of Ibadan in Oyo State and Benin in Edo state Nigeria. Firstly, the analysis of the understanding of the concept of leisure among the indigenes of Ibadan and Benin, what the people of Ibadan and Benin consider being leisure and how they defined leisure. Based on the findings, we can infer that, the definitions of leisure among Benin and Ibadan indigenes were very similar. All of the respondents in Benin were of the opinion that the time people spent for fun is "Eghe-imiobo" (i.e. free time).This is free time to do those things that gives joy, fun, happiness, release tension of things that borders the mind. There was a consensus among some participants that free time must be spent productively and not just for anything negative. To have a free time, a person have to feel free to use his or her time in whatever way he or she chooses but certainly not in "deviant recreation" and must be free from obligations or compulsory activities and there should be no forceful measures as to how to spend this time.

\section{Similarities and Differences in Factors that Condition Leisure in Ibadan and Benin.}

While the interviews helped to understand much about the meaning of leisure and leisure behaviours among Ibadan and Benin, The findings showed that in both locations, family factors, economic conditions, social influences, and religion, were the major forces that shaped leisure behaviour of the participants. First, most of the interviewees in Ibadan and Benin were of lower socio-economic status. Money was often a major constraint 
not only on their leisure participation but also on their daily lives. The majority of the participants commented that if they had more money they would organize more leisure activities for their families, travel with their relatives, or buy cars with a pool. Thus, it can be said that the participants considered money as a stepping stone that could lead to improved family recreation. Interestingly, some of the interviewees claimed that socio-economic status conditioned not only the activities that people could participate in, but also their leisure preferences.

Secondly, some participants from Benin claimed that much of their leisure revolved around festivities such as Igue Festivals, Independence Day, Christmas and Easter, local ethnic celebrations such as (Ugie-Ewere:-A festivity in which all evil spirit are chased away with fire before dawn and the "leave of joy (Ebe-Ewere)"are returned. This event takes place as part of the New Year celebration. It was initiated by King Eware, Sons and daughters of Ugo N' Iyekeorhiomwon every person living all over the country arrived home to celebrate the annual festivals of Igue, Ekpo, Isosun and Ekaba. The celebrations usually spill over to the New Year and provide an opportunity for all these indigenes of the area living beyond its boundaries to meet with relations and friends at home. For some reasons, these people are coming home for the first time after several years, most especially if they are living abroad. Families and friends would plan outings and large parties around these holidays. Such festivals and celebrations have been so internalized by the Benin's that they were the source of pride and a sense of belonging. Participants who resided in Ibadan also followed this holiday calendar, although celebrations among the indigenes were infused with different local ethnic celebrations different from that of Benin such as:"Egungun Festival", Eid-el-Fitri, Eid-el- Maolud and Eid-el-Kabir". Egungun is celebrated in festivals (Odun Egungun) and family ritual through the masquerade or custom Adepegba, (1984).

Here is the comments made by one of the participants from Ibadan, "My parents have always been Christians, my mother very much so however, she understood the satisfaction that everyone derives from the excitement leading up to Egungun festival, because of this my siblings and I are super obedient around the festival time so were many children in my neighborhood". Egungun is a part of the Yoruba pantheon of divinities and report has it that, it attracts a wide array of celebrants from across the length and breadth of Nigeria and the world, another is the "Oke'badan festival", celebrating the founding of Ibadan land Kareem (2013), just to mention but a few.

Thirdly, the findings showed that religious obligations, staying with families and hanging out with friends at restaurants and beer parlous, watching films and other enlightening programmes like documentaries about history, conditioned leisure activities of the majority of participants. Many interviewees believed that their family roles and daily life were shaped by the religious culture of their localities. Interestingly, although some of the interviewed revealed that they were no longer practically involved fully, they still believed their religious upbringing still had a strong effect on the choices they made with respect to leisure.

Lastly, it is therefore noteworthy that, the understanding of leisure concept and leisure behaviour of the people of these communities under study is a true representation of the non-western preferences and choices of leisure participation. Therefore, the people of these communities and other communities in Africa should be encouraged to participate in the activities of their choice when it is not against the norms and mores of the society and it is those activities that make them pleasant, joyful and refreshing.

\section{Conclusions of the Study}

The comparison of every aspect of leisure between Ibadan and Benin Metropolises was carefully examined and the result showed that there is no significant difference in the variables compared. In all, it is not all activities that are leisure in nature; therefore, those that are injurious to individual and community health should be discouraged while those that are health-promoting should be encouraged for the promotion of a healthy living and wellbeing.

\section{Recommendations}

Based on the findings of the study it is therefore recommended that:

1. Due to the similarities in the leisure concepts and other variables of leisure experiences, the involvement in leisure practices and participation should be sustained so as to foster unity, social interactions which can serve as a veritable tool for happiness, self-fulfillment and greater satisfaction among the people as they settle in each other's community.

2. Socialization during picnics, barbeques, and outings has an important meaning for members of these groups as they attempt to relax by having the family together while they drink, talk and participate in free play which further foster unity, peace and development in these domains. The traditional family time is very important to the people, although to a lesser degree many no longer live with their close family members due job placement and members seeking for greener pastures.

3. There should be more and proper orientation about the concept of leisure in the two localities; Health promoting leisure activity through active 
participations should be encouraged in order to discourage more of sedentary life style.

4. There should be proper orientation about the benefits of participation in leisure activities.

5. Perceptions concerning the extent to which people value their free time should be examined more closely as a potential source for leisure participation.

6. And as such parents must spend time with their children during family recreation, no matter how tight the schedule may be, we must start at the family level to reintroduce the norms and values which we grew up with. This reintroduction can be made possible through reuniting the family during free play and communal service.

7. The government and other stakeholders are essential for the planning and management of the wide array of leisure and culture opportunities. They should as a matter of urgency create an enabling environment for arts and culture to thrive. And also create conducive atmosphere by building recreation and leisure centers for youth participation in leisure activities as a means of curbing youth restiveness.

8. Leisure tourism can be encouraged by both individual stakeholders and government which in turn can attract investors to boost the economy of any community and nations.

9. Leisure practitioners and other experts should design recreation programmes for this population considering the demands for family recreation.

10. Quality social interaction that encompasses the need to engage in some forms of activities for ourselves and people, the existence of supportive relationships and social cohesion should be encouraged to further create an atmosphere that is calm and void of quagmire.

\section{Contribution to Knowledge}

Cross-cultural studies of leisure, such as this one, can test new grounds and examine the understanding of the concept and the meanings of leisure among the non-Western populations. This study has allowed us to make comparisons and identify transformations experienced by the natives of the two areas, by way of values attached to their culture, norms, values and traditions, and how their free time means so much when participating in these activities of their choice.

This study also confirmed the important role spending useful free time plays in the lives of the people, in uniting, and strengthening the bonds of oneness that keep them together which automatically are transferred to better the lots of the society for peaceful co-existence. As a result, it shed new light on the findings of studies by other leisure researchers in the future.

\section{Suggestion for Future Research}

A suggestion for future researchers who attempt to explore the understanding of leisure among groups of people would be to conduct similar studies with people from other regions of Nigeria and Africa to see if these results are consistent across different sub-populations. Future research should also investigate people from different regions to identify the impact of culture, religion, and local traditions on their understanding of leisure, the meaning of leisure, and the activities that they choose to participate in.

\section{Appendix 1 (Qualitative)}

\section{Questionnaire for Benin and Ibadan indigenes}

Identify what is considered as leisure among the people, when and in what situation it occurs

1. What are the activities that people in this community do for fun during their free time?

2. What are your favorite ways of spending free time?

3. What do you like to do for fun?

4. What does free time mean to you?

5. When are you enjoying yourself the most?

6. When do you participate in most of your fun activities?

To identify what properties activities need to possess to be described as leisure by members of this community

1. What is so special about the activities that you like to do for fun?

2. Are there any obligations you must perform during your (fun) activities?

To examine the meaning of leisure activities for members of the community

1. What do those funs mean to you?

2. How do you feel when participating in these activities and why do you participate in them?

To identify how the concept of leisure is categorized among members of this group

1. What do you call the activities you perform for fun and what do you call the time you use to participate in the activities you do for fun?

To examine forces that shapes the experiences of leisure among the people of this community

- Are there any fun activities you would like to participate in but are not able because of lack of money?

- Does the type of work you do affect the leisure activities that you can participate in? 
- Are there any religious or cultural celebrations that you participate in? Do you have fun participating in them, or you do them more because of an obligation?

- Do you practice a religion or faith? And does it affect your preferences or choices for fun activities?

\section{REFERENCES}

[1] Australian Bureau of Statistics 2004, Work in selected culture and leisure activities April 2004, cat. no. 6281.0, ABS, Canberra

[2] Akinwunmi. A 2016 domestic-violence-traceable-dysfunct ional-family-background http://www.vanguardngr.com

[3] Adedimeji, Mahfouz 2006 Globalization and the Survival of the Nigerian Cultural and Linguistic Heritage: The American Paradigm. Department of English, University of Ilorin, Nigeria.

[4] Adepegba, C.O. 1984. Yoruba Egungun: Its association with ancestors and the typology of Yoruba masquerades by its costume. Ibadan, Nigeria: University of Ibadan.

[5] Critcher, C.; Bramham, P. and Tomlinson, F. 2001. Sociology of Leisure New York: Spoon Press an imprint of the Taylor and Francis Group. Education. International Journal of African and African American Studies 4(2)

[6] Ipinmoroti, O.A. 2004. Provision of recreational facilities. An imperative for the Nigerianschool system. Education today. A quarterly journal of the Federal Ministry of Education. 1(1) 4-9.

[7] Kareem K.A 2013, Okebadan-a- hill-of-historical-significa nce. http:/www.vanguardngr.com

[8] Kunle, S. 2004 Nation of people who are mostly located in the Midwest part of Nigeria, Western Africa "Yoruba and Benin Kingdoms": The missing gap of history. http://www.edo-nation.net.

[9] Lucas, R; 2003. Personality, culture, and subjective well-being: Emotional and cognitive evaluations of life, Annual Review of Psychology, 54: 403-425.

[10] Lamont, M., and V. Molnar. 2001. How blacks use consumption to shape their collective identity: Evidence from marketing specialists, Journal of Consumer Culture, 1: 3146 .

[11] Oni, A 2005 Globalization and Its Implication on African Culture and Development: Challenges for Education. International Journal of African and African American Studies 4(2)

[12] Odumuh, T.O. 2004. Provision of recreational facilities as a remedy for youth restiveness. Education today. a quarterly journal of the Federal Ministry of Education, (1) $15-18$.

[13] Ojua, T. and Omono, C.2012. African Sacrificial ceremonies and issues in socio-cultural Development. British Journal of Arts and Social Development, 4: 1.

[14] Priestly, S. and Gass, M, A. 2005 Effective Leadership in Adventure Programming (2nd ed). Leeds: Human Kinetics.
[15] United Nations. 1998. Article 3 under the convention on the right of the child. United Nations General Assembly.

[16] United Nations 2006.Article 30 of the draft convention of rights of persons with disability. United Nations Organization.

[17] WHO, 2007 Female Genital Mutilation (FGM), US Department of State, http://www.state.gov/g/wi/ris/rep/crfg $\mathrm{mWHO}$ fact sheet www.who.int/mediaactive/factsheet/cult uralpracticesandhealth/e 